\title{
NURSING STUDENTS' CHALLENGES REGARDING THEIR EXPECTATIONS AND SATISFACTION BEFORE AND AFTER ATTENDING DELIVERY ROOM
}

\author{
Fatma Zaki Mohamed Farahat ${ }^{1}$, Nor El-Hoda Mohamed El-Sayed El-Shabory ${ }^{2}$, \\ Shymaa Abdel rahman osman abdel haleem ${ }^{3}$ \\ Lecturer of Maternity, Gynecology and obstetrics Nursing, Faculty of Nursing, Port Said \\ University, Port Said, Egypt ${ }^{1,2,3}$
}

\begin{abstract}
Background:It is dynamic and difficult to study midwifery, and is students accepted into the labor wards or not this affects the students learning. Therefore the study aimed to assess the challenges of nursing students regarding their expectations and satisfaction before and after entering delivery room. Method: An exploratory descriptive study design was used Sample: A purposive sample, all technical institute nursing students (91) who were attending the delivery unit during studying maternity and neonatal nursing course at study year 2018-2019, Setting: in General Damietta hospital. Tools: two tools, a selfadministered questionnaire of three parts was developed by the researchers, includes questions about the students' expectations, students' knowledge about labor and satisfaction, and a modified scale was also used. Results: Regarding students' expectations more than two third of students expected to be welcomed from mothers, and around half of students expected that nurses following the principle of infection control, nurses instructed women regarding bearing down and less than two-thirds of them were satisfied with the practical training and a sense of belonging and identity. Conclusion: Nursing students are faced with many challenges in the clinical learning, there were highly statically significant differences found between before and after entrance for many of their expectations, and some 'expectations were achieved. Students were satisfied with their clinical achievements after attending delivery room. Recommendations: Implement Students orientation programs pre attending delivery room include, prepare students, avoid causes of students fears and anxiety, and increase training through simulators, videos and integration of nursing ethics.
\end{abstract}

Keywords: Challenges, Delivery Room, Expectations, Nursing students, Satisfaction. 


\section{INTRODUCTION}

Midwifery is associate art therefore; nearly all students (male or female) in a midwifery course will be displayed to clinical experiences. Additionally, for maternity students to render safe follow-up to patients, they need to be professionally bolstered and radiocontrolled on the thanks to be specialists. A few expert affiliations have created clinical practice rules for use in clinical settings and consolidate male during this branch (AlGailani, 2016).

Pregnancy and birth are physiologic processes that are typically natural for each woman. Delivery room was the heart of the maternity ward and it was important to provide a safe and supportive environment for the mother and baby during delivery in order to do so treatment is administered by professional and experienced team of midwives and physicians from the department of obstetrics and gynecology (Canobbio et al., 2017).

It is complicated and vulnerable to work in delivery rooms as a nurse. The labour method is volatile and can become complicated easily. Midwife nurses are responsible for each mother and baby's wellbeing. The time slot isclosed, and the baby can be heavily penal ised by misjudgments. The exceptional essence of providing rooms affects the study of mid wifery college students (Coldridge \& Davies, 2017).

During child birth, the treatment of women and their relatives is a lucrative yet stressfulstrength in nursing.It is complicated and vulnerable to work in labour wards as a mi dwife. The method of labour is unpredictable and can becomecomplex quickly. So, the midwife nurse has to be careful and alert as time is tight and it can cause wrong decisions in the life of the mother and the fetus. (Arnold et al., 2019).

In shifting from the position of unbiased nurse to midwife, nursing college students Facedchallenges. The coping mechanisms used by midwife students concerned returning to nursing pursuits. Students of Midwifery may have several sources of stress in labour wards, such as the learning climate boss, the need to stabilise the requirements of evaluating and do mestic lifestyles, and the need to cope with life-and-death situations (Bäck et al., 2017).

Nursing students had high expectations of their active participation in childbirth care and tend to underestimate the feeling of altruism that motivates women to allow student's participation.Women have low expectations of the level of involvement of students in their 
treatment, but they leave with the students ' skills overall. These gaps illustrate the need for educational goals to be established to explain student roles in clinical clerk ships and steps to take the informed mother's consent process for student's engagement (Yacob, 2019).

\section{Significant of the study:}

Nurses' competence is based on the knowledge and skill taught to them (Manninen, 2012). Nursing training is a combination of theoretical and practical learning experiences that enable nursing students to acquire the knowledge, skills, and attitudes for providing nursing care (Nabolsi et al., 2012). In Iran and many other countries, clinical education forms more than half of the formal educational courses in nursing (Yousefy, Yazdannik, and Mohammadi, 2015). Therefore, clinical education is considered to be an essential and integral part of the nursing education program (Kalkhoran, 2013).

As there were few studies finding problems facing nursing students beforeand after entering the delivery room in terms of aspirations and satisfaction.

Completing the gaps in midwifery literature by shedding light on position conflicts for students, midwives and patients linked to cultural constraints and barriers.

Anursing shortage has continued to play a major role in the healthcare sysem over the last twenty years, and hospitals are reducing the clinical opportunities for student nurses because of the nursing shortage, as well as the number of students they are able to consider for a rota tion (Zboril,2016).

Requesting staff nurses to supervise these learners adds new duties that can impede the staff nurse from offering healthy patient care.

In doing so, the study reinforced the urgent need to identify the difficulties ofacing nursing students before and after entering the delivery room in terms of aspirations and satisfaction.

\section{AIM OF THE STUDY}

This research was aimed at assessing nursing students' challenges regarding their expectations and satisfaction before and after attending delivery room.

\section{Research questions:-}

1- What are the nursing students' expectations before and after attending delivery room?

2- Are nursing students satisfied after attending the delivery room? 


\section{SUBJECTS AND METHOD:}

Research design: An exploratory descriptive study design was used to conduct this study.

Setting: The delivery unit in obstetric department, General Damietta hospital at Damietta city, Egypt.

Sample: A purposive sample. All technical institute nursing students (91) who were attending the delivery unit during studying maternity and neonatal nursing course at 20182019 ,

\section{Tools of the Study: Two tools were used for data collection:}

The first tool: a self-administered questionnaire of three parts (Part I, II \& III):

Part I: The first part presented general characteristics as age, sex, education, and residence.

Part II: The second part includes questions about the student nurses' expectations before and after attending delivery room, it included questions related to first, second and third stages of labor.

Questions about their expectations before entering the delivery room and what they actually found when entering during the first stage:

\section{First: During the first stage of birth, such as:}

The health team welcomes students, how much does the health team want students to attend in the delivery room, do mothers welcome the presence of students or not? The presence of adequate capabilities and needs for mothers in the delivery room, the extent of the efficiency of the care provided to mothers during this stage, how the health team deals with mothers during this stage, what students can do to help mothers and the health team during this stage, the students' reaction and feeling or their response when hearing a cry Mothers suffered during this stage.

\section{Second: During the second and third stage of birth, such as:}

Expect them to witness the delivery of the fetus and placenta, their expectation that mothers will suffer at this stage. Mothers desire for students to be there to support them, how the health team and workers deal with mothers during this stage and the role and responsibility of each of them, their expectation of the results of childbirth, their expectation of the role that students can play during this stage, their response, feelings and impressions about childbirth and the extent of its difficulty and the extent of their personal influence so.

\section{Third: the role of the student in relation to his relationship with mothers:}

The psychological and emotional responses of students during childbirth and their influence, such as their feeling of fear, shyness, or fainting, headaches, tension, and their ability to control these feelings and overcome them in order to be able to provide assistance to mothers, and whether attending the birth is a pleasant thing or not.

\section{Fourth: the role of the student in relation to the newborn:}

Expecting a healthy baby, expecting the baby's needs as clothes and other things, and whether they have the ability to receive the newborn baby, cut the umbilical cord and examine the placenta after its birth. 
Fifthly: the role of the nurse in implementing infection control methods:

She will wear protective clothing, wash hands, follow measures to avoid infection, and explain nursing procedures to mothers. As well as maintaining their privacy during those procedures.

\section{Sixth: For the delivery room:}

Such as its cleanliness, avoiding loud sounds, the availability of crisis capabilities, the appropriate temperature for the mother and her baby, .....,...

Seventh: Regarding the instructions that the nurses must provide to mothers before leaving the department:

Such as treatment, cord care of baby, follow-up, and others, ..., ...

Part III: The third part includes student nurses' satisfaction after attending delivery room using satisfaction questionnaire.

First: the physiological needs of mothers, the cleanliness and ventilation of the delivery room, the availability of good lighting, the availability of the necessary facilities for work, the availability of a private bathroom for mothers, and the availability of a wheelchair for transporting mothers.

Second: Security and safety: -

Their feeling of safety and security while performing the work, applying adequate precautions to prevent infection, avoiding risks, the presence of supervision and follow-up, the presence of support and assistance from those in charge of supervising and from the teaching entity, as well as the presence of guidance and counseling.

Third: Affiliation: -

The existence of a good relationship between students and the supervisors of the hospital and Teaching staff. As well as between them and their colleagues and between them and between the doctors and the rest of the members of the health team and between them and the staff and workers. The vacancy of the students with satisfaction for their participation in the birth process and for their gaining practical experience from it.

Fourth: Respect:

Students' feeling of respecting others during their presence, including nurses, doctors, and others, and they were encouraged by members of the health team and Teaching staff, and whether the criticism and revelation took place in a private place or not, and did they interfere in criticizing their own behavior and professional ethics, and would they be thanked and appreciated by patients.

Fifthly: Self-realization: - 
Their feeling of achieving the goals of the practical training in the Department of Obstetrics and Gynecology, their feeling of an important and effective blindness, are they given the opportunity for practical training, do they have the opportunity to learn about the experiences of others, and about the methods and modern equipment during childbirth, do they feel satisfied with their achievements during practical training in a room Are they happy to help others, have they gained much experience, and is childbirth a difficult and cruel process from their point of view?

\section{The second tool:}

A National League for nursing' scale, (2013) was adapted to measure the scientific experience of nursing students regarding their expectations and satisfaction. It has 5 objects that were originally intended to assess students' satisfaction with a simulated task. The scale was modified in this study; to assess students' satisfaction with the two assigned mastery experiences, whether simulated or traditional, by replacing the term simulation with clinical training. Satisfaction score ranged from 5 to 15, the higher score indicates more satisfaction.

Scoring system: The score is given as follows:

Satisfied with the practical or clinical training $=(1)$

Degree of unsatisfied with the practical or clinical training $=(0)$

- Students were considered satisfied with practical or clinical training when the overall registered percentage was $60 \%$ or more.

- Students were considered unsatisfied with practical or clinical training when the overall percentage of enrollment was $<60 \%$.

\section{Field work:}

A permission to conduct the study was obtained from the head of the_Technical Institute of Nursing and the teaching staff prior to administration of the questionnaire. After gaining approvals for conducting the research and coordination with students' Affairs officer in gaining information about students' schedules and times of clinical training. The students were informed by the researchers about the study aim. the students (91 technical institute nursing students) who were attending the delivery unit in obstetric department during studying maternity and neonatal nursing course at 2018-2019, General Damietta hospital, they were instructed on how to fill out the questionnaire completely and truthfully and thy were divided into 8 groups, each group consisted of 5 to 6 students, and the number of days was two days every week, and the time for filling out the form took about 20 minutes. From 
the beginning of current study till analysis of results, the study took two months for data collection, data collected from September and October 2018.

\section{Pilot study:}

A Pilot study was carried out after the development of the questionnaire on $10 \%$ (9 students) of the technical institute nursing students to test the applicability and the visibility of the questionnaire then the necessary modifications were done according to the results of the pilot study. The students included in the pilot study were excluded from the total sample

validity was measures by jury of expertise consisted of five professors from maternity, gynecology and obstetrics health nursing.

Data collection was started and finished at three months from the beginning of November 2018 to beginning of January 2019. Second of questionnaire was repeated after student attendance with delivery room after two weeks to assess student expectations post attending the training in the delivery room. Third part of questionnaire was utilized after student attendance with delivery room to assess the nursing student satisfaction

The reliability of the study questionnaire was $(\alpha=0.85)$ and the content

\section{Ethical consideration:}

All ethical issues were taken into consideration during the study; the acceptance of ethical comity o faculty of nursing is taken, the researcher maintained an anonymity and confidentiality of the subjects. She introduced herself to the students and briefly explained the nature and aim of the study to every student before participation, and women were enrolled voluntarily after written consent. student were also assured that all information obtained during the study was confidential and used for the research purpose only and they have the chance to withdraw from the study when they want.

\section{Statistical analysis:}

The data was collected, coded, and entered to a personal computer (PC) IBM compatible 2.6 GHZ. It was analyzed with the program (SPSS) statistical package for social science under windows version 11.0.1. The collected data were organized, revised, analyzed, tabulated using number and percent distribution. Proper statistical tests were used to determine if there were statistically significant differences between variables of the study. Statistically significance was considered at $\mathrm{p}$-value $<.05$. Chi-square test was used in this study to compare non parametric data.

\section{RESULTS:}

Table (1): shows that $54.9 \%$ of study sample were in the age group of less than 20 years, $94.5 \%$ of studied sample was female and most of the students $(74.7 \%)$ were living in rural areas. 
Table (2): The table show that there were statically significant differences found in all expectations during first stage of labor between before and after entrance except for expectation of regular assessment of mothers condition by physician(70.3\%-57.1\%). $\mathrm{p} \leq$ 0.05

Table (3): shows that there were highly statically significant differences found between before and after entrance according to Student nurse' expectations during $2^{\text {nd }} \&$ third stage of labor as Labor and delivery process is hard (62.6\%-83.5\%), except in expectations of seeing delivery of fetus and placenta from vagina (63.7-75.8). $\mathrm{p} \leq 0.05$.

Table (4): showed that there were highly statically significant differences found between before and after entrance according to Student nurse' expectations during $2^{\text {nd }} \boldsymbol{\&}$ third stage of labor except in expectations of Transporting of mothers $(71.4 \%-84.6 \%)$. $\mathrm{p} \leq$ 0.05

Table (5): showed that there were highly statically significant differences found between before and after entrance according to Student nurse' expectations during $2^{\text {nd }} \boldsymbol{\&}$ third stage of labor except in, Fear of acquiring infection from delivery room (65.9\%$70.3 \%$ ), and Deficit of infection control measure (40.7\%-57.1\%). $\mathrm{p} \leq 0.05$

Table (6): showed that there were statically significant differences found during childbirth between before and after entrance in delivery room regarding their feelings, affect and reactions while attending childbirth, expectations of sharing in nursing care provided for mother. On the other hand, there were no statistical significant differences found during childbirth between before and after entrance in other expectations $\mathrm{p} \leq 0.05$.

Table (7): showed the Comparison between before and after entrance according to relation with mother. The table show that there were no statically significant differences found between before and after according to relation with mother $\mathrm{p} \leq 0.05$.

Table (8): revealed the labor expectation satisfaction. More than half of student nurses (57\% and 54\%) were satisfied with belonging and identity.48\%, $45 \%$ and $43 \%$ were reported satisfied of Respect, Safety measures in the delivery room and delivery room environment after entrance delivery room.

Table (1): Frequency distribution of the studied students according to demographic data $(\mathrm{n}=91)$

\begin{tabular}{|l|c|c|}
\hline \multicolumn{1}{|c|}{ Demographic characteristics } & No.=91 & \% \\
\hline Age & \multicolumn{2}{c|}{} \\
$<20$ & 50 & 54.9 \\
$\geq 20$ & 41 & 45.1 \\
\hline \multicolumn{2}{|c|}{ Min. - Max. } & \multicolumn{2}{|c|}{$18.0-23.0$} \\
\multicolumn{2}{|c|}{ Mean \pm SD. } & $86.56 \pm 0.92$ \\
\hline Sex & 5 & 94.5 \\
Female & \multicolumn{2}{|c|}{5.5} \\
Male & 68 & 74.7 \\
\hline Residence & 23 & 25.3 \\
Rural & \\
Urban & \multicolumn{2}{|c|}{} \\
\hline
\end{tabular}


Table (2): Student nurse' expectations before and after entrance delivery room during the first stage of labor $(\mathrm{N} .=91)$

\begin{tabular}{|c|c|c|c|c|c|c|c|}
\hline \multirow{3}{*}{\multicolumn{2}{|c|}{$\begin{array}{l}\text { Student nurse' expectations during first } \\
\text { stage of labor }\end{array}$}} & \multicolumn{4}{|c|}{ Frequency } & \multirow{3}{*}{$\chi^{2}$} & \multirow{3}{*}{$\mathbf{P}$} \\
\hline & & \multicolumn{2}{|c|}{$\begin{array}{c}\text { Before Entrance } \\
(\mathbf{n = 9 1 )}\end{array}$} & \multicolumn{2}{|c|}{$\begin{array}{c}\text { After Entrance } \\
(\mathrm{n}=91)\end{array}$} & & \\
\hline & & No. & $\%$ & No. & $\%$ & & \\
\hline 1 & Health team welcomed students nurses & 67 & 73.6 & 35 & 38.5 & $\begin{array}{c}27.08 \\
9^{*}\end{array}$ & $\begin{array}{l}<0.0 \\
01^{*}\end{array}$ \\
\hline 2 & $\begin{array}{l}\text { Health team didn't want student } \\
\text { presence in the delivery room. }\end{array}$ & 48 & 52.7 & 32 & 35.2 & $\begin{array}{l}6.412 \\
*\end{array}$ & $\begin{array}{c}0.03 \\
7^{*}\end{array}$ \\
\hline 3 & Mother welcomed student nurse. & 53 & 58.2 & 30 & 33.0 & $\begin{array}{c}15.66 \\
0^{*}\end{array}$ & $\begin{array}{l}<0.0 \\
01^{*}\end{array}$ \\
\hline 4 & $\begin{array}{l}\text { Available and enough instruments, } \\
\text { equipment and disinfectant solution. }\end{array}$ & 56 & 61.5 & 35 & 38.5 & $\begin{array}{c}16.91 \\
9^{*}\end{array}$ & $\begin{array}{l}<0.0 \\
01^{*}\end{array}$ \\
\hline 5 & Presence of wheel chairs & 56 & 61.5 & 33 & 36.3 & $\begin{array}{c}12.81 \\
4^{*}\end{array}$ & $\begin{array}{c}0.00 \\
2^{*}\end{array}$ \\
\hline 6 & $\begin{array}{l}\text { Early transportation of mothers to } \\
\text { delivery room. }\end{array}$ & 67 & 73.6 & 48 & 52.7 & $\begin{array}{c}11.74 \\
6^{*}\end{array}$ & $\begin{array}{c}0.00 \\
3^{*}\end{array}$ \\
\hline 7 & $\begin{array}{l}\text { Regular assessment of mothers' } \\
\text { condition by physician. }\end{array}$ & 64 & 70.3 & 52 & 57.1 & 5.314 & $\begin{array}{c}0.05 \\
1\end{array}$ \\
\hline 8 & $\begin{array}{l}\text { Explaining of each procedures to } \\
\text { mother before its implementation. }\end{array}$ & 52 & 57.1 & 38 & 41.8 & $\begin{array}{l}5.709 \\
*\end{array}$ & $\begin{array}{c}0.04 \\
7^{*}\end{array}$ \\
\hline 9 & $\begin{array}{l}\text { Immediate response to mother } \\
\text { complains. }\end{array}$ & 60 & 65.9 & 44 & 48.4 & $\begin{array}{c}11.51 \\
5^{*}\end{array}$ & $\begin{array}{c}0.00 \\
3^{*}\end{array}$ \\
\hline 10 & Provide privacy for each mother. & 59 & 64.8 & 46 & 50.5 & $\begin{array}{c}12.92 \\
2^{*}\end{array}$ & $\begin{array}{c}0.00 \\
1^{*}\end{array}$ \\
\hline 11 & $\begin{array}{l}\text { Available of nurses in the delivery } \\
\text { room. }\end{array}$ & 60 & 65.9 & 48 & 52.7 & $\begin{array}{l}6.224 \\
*\end{array}$ & $\begin{array}{c}0.03 \\
4^{*}\end{array}$ \\
\hline 12 & $\begin{array}{l}\text { Nurses encouraging mothers to walk } \\
\text { during 1st stage of labor }\end{array}$ & 75 & 82.4 & 43 & 47.3 & $\begin{array}{c}25.08 \\
8^{*}\end{array}$ & $\begin{array}{l}<0.0 \\
01^{*}\end{array}$ \\
\hline 13 & Nurses instructed mother to void. & 70 & $\begin{array}{c}676 . \\
9\end{array}$ & 45 & 49.5 & $\begin{array}{c}18.50 \\
1 *\end{array}$ & $\begin{array}{l}<0.0 \\
01 *\end{array}$ \\
\hline 14 & $\begin{array}{l}\text { Providing perineal hygiene before } \\
\text { vaginal examination. }\end{array}$ & 68 & 74.7 & 45 & 49.5 & $\begin{array}{c}15.56 \\
3^{*}\end{array}$ & $\begin{array}{l}<0.0 \\
01 *\end{array}$ \\
\hline 15 & $\begin{array}{l}\text { Nurses always informed mothers about } \\
\text { labor progress }\end{array}$ & 66 & 72.5 & 45 & 49.5 & $\begin{array}{c}14.50 \\
0 *\end{array}$ & $\begin{array}{r}0.00 \\
1^{*}\end{array}$ \\
\hline 16 & $\begin{array}{l}\text { Nurses following principles of infection } \\
\text { prevention measures in the delivery } \\
\text { room. }\end{array}$ & 55 & 60.4 & 36 & 39.6 & $\begin{array}{c}17.40 \\
8 *\end{array}$ & $\begin{array}{r}<0.0 \\
01 *\end{array}$ \\
\hline 17 & Feeling of fear when mother cry . & 59 & 64.8 & 43 & 47.3 & $\begin{array}{c}10.39 \\
3 *\end{array}$ & $\begin{array}{l}0.00 \\
5^{*}\end{array}$ \\
\hline
\end{tabular}

$\chi^{2}, \mathrm{p}: \chi^{2}$ and $\mathrm{p}$ values for Chi square test

*: Statistically significant at $\mathrm{p} \leq 0.05$ 
Table (3): Student nurse' expectations before and after entrance delivery room during the second \& third stage of labor (regarding Process of labor), (N. =91).

\begin{tabular}{|c|c|c|c|c|c|c|c|}
\hline \multirow{3}{*}{\multicolumn{2}{|c|}{$\begin{array}{c}\text { Student nurse expectations regarding process } \\
\text { of labor }\end{array}$}} & \multicolumn{4}{|c|}{ Frequency } & \multirow{4}{*}{$\frac{\chi^{2}}{0.733}$} & \multirow{4}{*}{$\begin{array}{c}\mathbf{P} \\
0.693\end{array}$} \\
\hline & & \multicolumn{2}{|c|}{$\begin{array}{l}\text { Before Entrance } \\
(\mathbf{N}=91)\end{array}$} & \multicolumn{2}{|c|}{$\begin{array}{c}\text { After Entrance } \\
(\mathbf{N}=91)\end{array}$} & & \\
\hline & & \multirow{2}{*}{\begin{tabular}{|l|} 
N. \\
43 \\
\end{tabular}} & \multirow{2}{*}{$\frac{\%}{47.3}$} & \multirow{2}{*}{$\frac{\mathbf{N} .}{41}$} & \multirow{2}{*}{$\frac{\%}{45.1}$} & & \\
\hline 1 & Seeing delivery of fetus from vagina & & & & & & \\
\hline 2 & $\begin{array}{l}\text { Seeing delivery of fetus and placenta from } \\
\text { vagina }\end{array}$ & 58 & 63.7 & 69 & 75.8 & 5.771 & 0.056 \\
\hline 3 & $\begin{array}{l}\text { Delivery of fetus was associated with } \\
\text { severe abdominal pain }\end{array}$ & 55 & 60.4 & 77 & 84.6 & $\begin{array}{c}16.502 \\
*\end{array}$ & $\begin{array}{l}<0.001 \\
*\end{array}$ \\
\hline 4 & Childbirth conducted spontaneously & 72 & 79.1 & 62 & 68.1 & $7.504 *$ & $0.023 *$ \\
\hline 5 & May be normal delivery convert & 55 & 60.4 & 73 & 80.2 & $8.603 *$ & $0.008 *$ \\
\hline 6 & Labor and delivery process is hard & 57 & 62.6 & 76 & 83.5 & $\begin{array}{c}11.048 \\
*\end{array}$ & $0.003 *$ \\
\hline 7 & Recording of delivery time & 81 & 89.0 & 54 & 59.3 & $\begin{array}{c}26.772 \\
*\end{array}$ & $\begin{array}{l}<0.001 \\
*\end{array}$ \\
\hline
\end{tabular}

$\chi 2, p: \chi 2$ and $\mathrm{p}$ values for Chi square test $\quad *$ : Statistically significant at $\mathrm{p} \leq 0.05$

Table (4): Student nurse' expectations before and after entrance delivery room during the second \& third stage of labor (regarding role of nurse), (N. =91).

\begin{tabular}{|c|c|c|c|c|c|c|c|}
\hline \multirow{3}{*}{\multicolumn{2}{|c|}{$\begin{array}{l}\text { Student nurse expectations regarding } \\
\text { role of nurse }\end{array}$}} & \multicolumn{4}{|c|}{ Frequency } & \multirow{4}{*}{$\frac{\chi^{2}}{19.649^{*}}$} & \multirow{4}{*}{$\frac{\mathbf{P}}{<0.001^{*}}$} \\
\hline & & \multicolumn{2}{|c|}{$\begin{array}{l}\text { Before Entrance } \\
(\mathrm{N}=91)\end{array}$} & \multicolumn{2}{|c|}{$\begin{array}{l}\text { After Entrance } \\
\quad(\mathrm{N}=91)\end{array}$} & & \\
\hline & & $\mathbf{N}$. & $\%$ & N. & $\%$ & & \\
\hline 1 & Nurse encourage mother to expulsion of the fetus & 76 & 83.5 & 51 & 56.0 & & \\
\hline 2 & $\begin{array}{l}\text { Mother cleanness after delivery by the nurse or } \\
\text { student }\end{array}$ & 50 & 54.9 & 31 & 34.1 & $10671 *$ & $0.005^{*}$ \\
\hline 3 & $\begin{array}{l}\text { Mother cleanness at delivery rooms was the workers } \\
\text { duties not by the nurse }\end{array}$ & 21 & 23.1 & 41 & 45.1 & $10.116^{*}$ & $0.006^{*}$ \\
\hline 4 & $\begin{array}{l}\text { Delivery bed cleanness at delivery rooms was the } \\
\text { workers duties not by the nurse }\end{array}$ & 41 & 45.1 & 60 & 65.9 & $8.045^{*}$ & $0.018^{*}$ \\
\hline 5 & $\begin{array}{l}\text { Transporting of mothers from delivery room to post } \\
\text { natal room by worker not by the nurse. }\end{array}$ & 65 & 71.4 & 77 & 84.6 & 4.703 & 0.115 \\
\hline 6 & $\begin{array}{l}\text { Observation of mother for } 4 \text { hours and } 15 \text { minutes } \\
\text { at least }\end{array}$ & 49 & 53.8 & 23 & 25.3 & $17.823^{*}$ & $<0.001^{*}$ \\
\hline 7 & $\begin{array}{l}\text { Cleaning for umbilical cord, observing of newborn } \\
\text { condition are responsibility of delivery room nurses } \\
\text { and students }\end{array}$ & 79 & 86.8 & 55 & 60.4 & $23.755^{*}$ & $<0.001 *$ \\
\hline 8 & $\begin{array}{l}\text { Administering of medication are responsibility of } \\
\text { delivery room nurse not student }\end{array}$ & 84 & 92.3 & 70 & 76.9 & $8.273 *$ & $0.004 *$ \\
\hline 9 & Recording of delivery time & 81 & 89.0 & 54 & 59.3 & $26.772 *$ & $<0.001 *$ \\
\hline
\end{tabular}

$\chi 2, p: \chi^{2}$ and $\mathrm{p}$ values for Chi square test $*$ : Statistically significant at $\mathrm{p} \leq 0.05$ 
Table (5): Student nurse' expectations before and after entrance delivery room during the second \& third stage of labor (regarding students role and infection control) (N. =91)

\begin{tabular}{|c|c|c|c|c|c|c|c|}
\hline \multirow{3}{*}{ 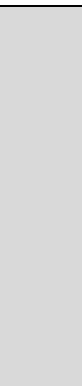 } & \multirow{3}{*}{$\begin{array}{l}\text { Student nurse expectations regarding } \\
\text { students role and infection control }\end{array}$} & \multicolumn{4}{|c|}{ Frequency } & \multirow{3}{*}{$\chi^{2}$} & \multirow{3}{*}{$\mathbf{P}$} \\
\hline & & \multicolumn{2}{|c|}{$\begin{array}{c}\text { Before } \\
\text { Entrance } \\
(\mathbf{N}=91)\end{array}$} & \multicolumn{2}{|c|}{$\begin{array}{c}\text { After } \\
\text { Entrance } \\
(\mathbf{N}=91)\end{array}$} & & \\
\hline & & $\mathbf{N}$. & $\%$ & N. & $\%$ & & \\
\hline 1 & $\begin{array}{l}\text { Mother refused student attendance } \\
\text { during delivery }\end{array}$ & 45 & 49.5 & 67 & 73.6 & $11.979 *$ & $0.003 *$ \\
\hline 2 & $\begin{array}{l}\text { Mother welcomed student } \\
\text { attendance beside her }\end{array}$ & 36 & 39.6 & 16 & 17.6 & $11.076^{*}$ & $0.003^{*}$ \\
\hline 3 & $\begin{array}{l}\text { Student nurse encourage mother } \\
\text { to expulsion of the fetus }\end{array}$ & 67 & 73.6 & 49 & 53.8 & $8.972 *$ & $0.012^{*}$ \\
\hline 4 & Student share in suction care of newborn & 48 & 52.7 & 26 & 28.6 & $12.295 *$ & $0.002 *$ \\
\hline 5 & $\begin{array}{l}\text { Student responsibility of } \\
\text { newborn identification }\end{array}$ & 48 & 52.7 & 25 & 27.5 & $15.124^{*}$ & $0.001 *$ \\
\hline 6 & Recording of delivery time & 81 & 89.0 & 54 & 59.3 & $26.772 *$ & $<0.001^{*}$ \\
\hline 7 & $\begin{array}{l}\text { Fear of acquiring infection from delivery } \\
\text { room }\end{array}$ & 60 & 65.9 & 64 & 70.3 & 1.836 & 0.511 \\
\hline 8 & Deficit of infection control measure. & 37 & 40.7 & 52 & 57.1 & 5.009 & 0.082 \\
\hline
\end{tabular}

$\chi 2, p: \chi^{2}$ and $\mathrm{p}$ values for Chi square test $\quad *$ : Statistically significant at $\mathrm{p} \leq 0.05$ 
Table (6): Student nurse' expectations before and after entrance delivery room regarding their feelings, affect and reactions while attending childbirth $(\mathrm{N} .=91)$.

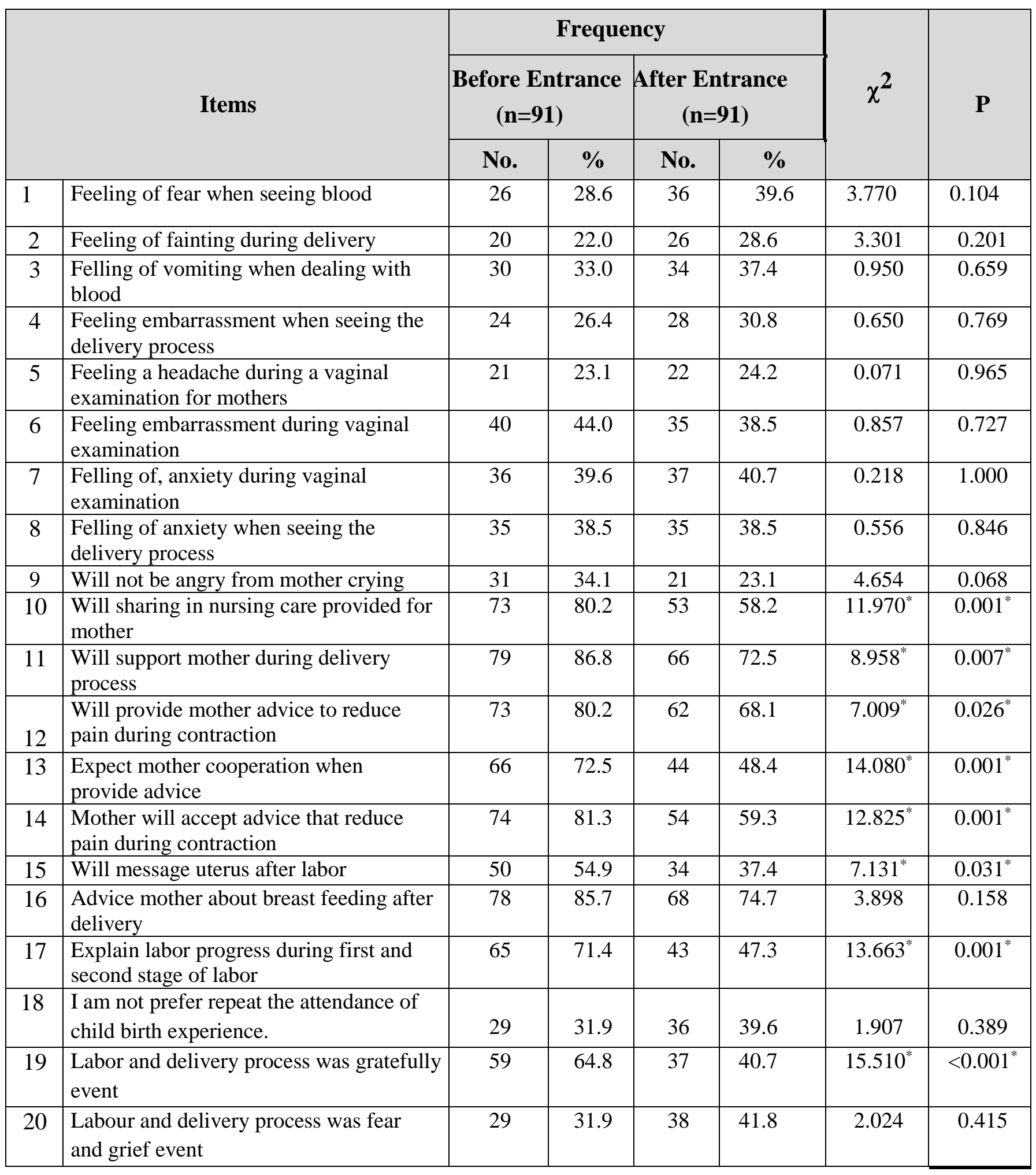


Table (7): Comparison between before and after entrance regarding the relation with mothers $(\mathrm{N} .=91)$

\begin{tabular}{|c|c|c|c|c|c|c|c|}
\hline \multirow{3}{*}{\multicolumn{2}{|c|}{ Relation with mothers }} & \multicolumn{4}{|c|}{ Frequency } & \multirow{3}{*}{$\chi^{2}$} & \multirow{3}{*}{$\mathbf{P}$} \\
\hline & & \multicolumn{2}{|c|}{$\begin{array}{c}\text { Before } \\
\text { Entrance } \\
(n=91)\end{array}$} & \multicolumn{2}{|c|}{$\begin{array}{c}\text { After } \\
\text { Entrance } \\
(n=91)\end{array}$} & & \\
\hline & & No. & $\%$ & No. & $\%$ & & \\
\hline 1 & Expected delivery of healthy newborn baby & 66 & 72.5 & 65 & 71.4 & 0.240 & 0.887 \\
\hline 2 & Presence of suitable clothes for baby & 77 & 84.6 & 77 & 84.6 & 1.652 & 0.426 \\
\hline 3 & Having ability for receive the newborn baby & 61 & 67.0 & 61 & 67.0 & 0.739 & 0.691 \\
\hline 4 & $\begin{array}{l}\text { Having ability for examination of } \\
\text { placenta and cord }\end{array}$ & 52 & 571.0 & 51 & 56.0 & 0.027 & 1.000 \\
\hline
\end{tabular}

$\chi^{2}, \mathrm{p}: \chi^{2}$ and $\mathrm{p}$ values for Chi square test $\quad *$ : Statistically significant at $\mathrm{p} \leq 0.05$

Table (8): Distribution of the studied students according to their satisfaction $(\mathrm{N} .=91)$.

\begin{tabular}{|c|c|c|c|c|c|c|c|}
\hline & \multirow{3}{*}{ Items } & \multicolumn{6}{|c|}{ Degree of students' satisfaction $\left(\mathrm{N}_{\mathbf{0}}=91\right)$} \\
\hline & & \multicolumn{2}{|c|}{ Satisfied } & \multicolumn{2}{|c|}{ Unsatisfied } & \multicolumn{2}{|c|}{ Not Sure } \\
\hline & & $\mathbf{N}$. & $\%$ & $\mathbf{N}$. & $\%$ & $\mathbf{N}$. & $\%$ \\
\hline 1 & Delivery room environment & 43 & 47.3 & 33 & 36.1 & 15 & 16.6 \\
\hline 2 & Safety measures in the delivery room & 45 & 50.1 & 38 & 41.5 & 8 & 8.5 \\
\hline 3 & Belonging & 57 & 63.7 & 28 & 30.8 & 5 & 5.5 \\
\hline 4 & Respect & 48 & 52.7 & 38 & 41.8 & 5 & 5.5 \\
\hline 5 & Identity & 54 & 59.3 & 32 & 35.2 & 5 & 5.5 \\
\hline
\end{tabular}

\section{DISCUSSION:}

The clinical environment whichis waiting to accumulate the

nursing students with the opportunities to attain that purpose is unfavorable; such environment limits the student's hazard to hands-on care. Support from supervisor and other staff, learning possibilities and performance of department management during training playan important role in the students' choice of employment (Kwashie, 2019). The present study supplemented this by assessing the nursing students' challenges regarding expectations and satisfaction before and after attending delivery room.

The results determined that; the mean studied students' ages was $<20$ years old that because the sample was from chosen female and male students who still in the academic years of the maternity course and more than half of them were from ruler areas, the ruler back ground may explain the finding of this study. This finding was in a similar line and 
agreed with the study done by Eswi and El Sayed, (2015) a study conducted in Egypt "The experience of Egyptian male student nurses during attending maternity nursing clinical course" and reported that the majority of the students were from the ruler areas.

This finding agreed with the study done by Joolaee et al., (2015) A study conduct in Iran "Iranian nursing students' preparedness for clinical training: a qualitative study," study, lack of self-confidence has been referred to as a major cause of fear and anxiety in nursing students. The researcher demonstrated in his study that lack of self-confidence also disturbs communication in nursing students. Moreover, having adequate self-confidence for caregiving is one of the most important factors affecting the students' learning.

This finding also agreed with the study done by Gaberson, and Shellenbarger, ( 2014). A study conduct in New York " Clinical Teaching Strategies in Nursing", study, self-confidence was an important part of a nurse's personal and professional identity. We found that nursing students are faced with many challenges in the clinical learning environment, which affect their professionalization and learning processes. Many students are not mentally prepared to enter the clinical environment leading to higher rates of psychological problems. Moreover, lack of adequate knowledge and skill along with lack of mental and psychological preparation disturbs the learning and patient caregiving.

The current study findings revealed that there were statically significant differences found in all nursing students' expectations during the first stage of labor between before and after entrance except for their expectation of regular assessment of mother's condition by physician. Nursing students indicated that some of their objectives and expectations had been no longer met at practical placement. Many students expected to be welcomed in the clinical setting.

The researchers opinion that, the health facilities should provide a conducive and supportive environment for students in clinical placement. Poor interpersonal relations between students and staff during clinical placement was experienced by student nurses and midwives. Many nurses and midwives also embarrassed students when they made mistakes in the wards. Some students stated that they were made to feel as if they were the worse ever human beings on earth. Midwife nurses play a high quality position as the key people serving as a function model in the gaining knowledge of technique of students through conversation based totally on respect, integrity, and mutual interplay with students. They can provide a psychosocial wonderful environment for college students getting to know in the ward. 
This finding agreed with the study done by (Baraz et al., 2015) A study conduct in Iran about 'Damaged professional identity as a barrier to Iranian nursing students' clinical learning: a qualitative study," It is mentioned that supportive relationships with college students have been used as a key to increase the scholar security in medical wards, especially among the first and second 12 months students. Supportive relationships set off internalization of the nursing role as a company of healthcare things to do (Jan \& Popescu, 2014)

This finding agreed with the study done by (Atakro, 2017) A study conduct in Ghana about "Experiences of student nurses and midwives at selected hospitals in the Volta region of Ghana", Atakro concluded in his study that conditions of name calling and the usage of college students as scapegoats compromised open and sincere interactions between college students and team of workers and this impacted negatively on students' learning. A practical environment with the essential help for college students is imperative to students' gaining of knowledge.

Clinical amenities with rich mastering opportunities have to also provide a conducive environment for students learning due to the fact proof handy shows that scientific surroundings with much less gaining knowledge of opportunities but greater medical learning guide and conducive environment was more favourable for students mastering than clinical settings with prosperous studying opportunities besides clinical studying support .Establishing caring relationships with students is key for growing caring mastering environments (Millanzi, \& Kibusi, 2020) A study conduct in Tanzania about "Exploring the Effect of Problem Based Facilitators Teaching Approach on Motivation to Learn in Nursing Education: A QuasiExperimental Study of Nurse Students in Tanzania" and its finding agreed with this study.

This is consistent with a study conducted via Mainey et al., (2020) who additionally observed in a study that student nurses and midwives in South Africa have been typically left on their personal to be taught by means of ward sisters. Similarly, medical nursing and midwifery schooling in Ghana is currently going through challenges of terrible working members of the family between hospitals and fitness coaching establishments (Bvumbwe \& Mtshali, 2018).

This finding not in the equivalent line and disagree with Nasser et al., (2018) a study conducted in Egypt " Perception of Junior Nurse Students and Nurse Interns Regarding Public Image of Nursing" and mentioned that Egyptian nurse students mainly male, societal 
image of nursing as profession considered one of the major reasons that put the male students under stress, in this study the majority of nurse students was female.

This finding agreed with the study of (Nishimi \& Street, 2020,) which was concluded that, studies by countless investigators reported positive findings of collaborative preceptor ship fashions between schools of nursing/midwifery and health provider organizations the place nursing and midwifery college students had a favorable experience, elevated their knowledge, expanded their confidence, and integrated their competencies with reallife conditions.

The present study showed that there were a significantly higher satisfaction scores regarding the assigned clinical experience among nursing students. Furthermore, midwife nursing students who attend childbirth classes imply higher satisfaction scores. (Marzouk, (2015) a study conducted in Egypt " Effectiveness of simulated delivery room classes on practical achievement and satisfaction of maternity nursing students" who supporting the present study findings, by means of evaluating the impact of simulation based training on baccalaureate nursing students' satisfaction and announcing that the students were very satisfied with the simulation learning undertaking with an average of 24.27 out of 25 feasible points. In this context, for effective clinical component of nursing education in Egypt community there must be a strong collaboration between nursing/ midwifery schools and health service, where teachers and faculty members are regularly participating in clinical teaching partnership (CTP) programs.

In accordance with this study, Çalım et al., (2020) had evaluated the students' satisfaction with the achieving experience on a subgroup of fifty three students; 27 uncovered to labor and delivery scenario of affairs based-simulation and 26 belonged to the self-study arm and discovered that $93 \%$ versus $54 \%$ respectively have been positively agreed with their mastering experience.

Also, in line with this finding, a quasi-experimental study evaluated the effect of a 3hour postpartum simulation exercise and found that there was a significant improvement in the self-efficacy ranges of nursing students and the degree of satisfaction in postpartum care of mothers (Weber, 2016) A study conduct in Ghana about "Closing the know-do gap in public health professional training: the case-method teaching approach". 
The present study finding ensures the Chinese proverb "Tell me, I will forget. Show me, I may remember. But involve me and I will learn." Whereas the students bridge the listening and showing phases to performance phase so the satisfaction degree increased.

The significantly higher level of satisfaction declared by simulation group students by a report by the fact that these students were given an opportunity to experiment, make a mistake and correct the errors that led to gaining confidence in providing care in a realistic practice setting and thus enhancing their levels of satisfaction.

The significantly higher satisfaction level that was announced by the students may be revealed by the fact that those students had given a chance to gaining selfassurance of imparting carein actual practice putting and inconsequence enhance their satis faction levels.

\section{CONCLUSION:}

In the light of the study, it is concluded that, Nursing students are faced with many challenges in the clinical learning, there were highly statically significant differences found between before entrance and after entrance according to Student nurse' expectations except some expectations were similar in some items and different in some others before and after entrance delivery room, as the results show that many of the students 'expectations were achieved as the students exceeded their expectations regarding majors, and bear the developments of events inside the delivery room. Students were satisfied with their clinical achievements after attending delivery room.

\section{RECOMMENDATIONS:}

- Implement Students orientation programs pre attending delivery room include how to prepare students and how to avoid causes of students fears, anxiety from attending delivery room, something very important and essential

- Increase training through simulators, videos and integration of nursing ethics to promote women's rights during child birth.

- Providing midwife students with training in childbirth simulation classes and scientific research prior to traditional medical training to consider the effect of simulation training on the use of scenarios in high-risk situations.

- Emphasize the effect of replacing traditional scientific training with evidence based methods of birth simulation lessons on practical achievement. 


\section{Declaration of conflicting interests:}

The authors declare that there is no conflict of interest

\section{Funding:}

The authors declare that they have not received any direct or indirect funding from any organization for the research.

\section{Acknowledgments:}

We would like to thank all the head of the Technical Institute of Nursing and the teaching staff, the nursing students and head nurses in obstetric department, General Damietta hospital at Damietta city, for their efforts to complete this research.

\section{REFERENCES:}

Al-Gailani, S. (2016). The "Ice Age" of Anatomy and Obstetrics: Hand and Eye in the Promotion of Frozen Sections around 1900. Bulletin of the History of Medicine, 90(4), 611.)

Arnold, R., Van Teijlingen, E., Ryan, K., \& Holloway, I. (2019). Villains or victims? Ethnography of Afghan maternity staff and the challenge of high quality respectful care. BMC pregnancy and childbirth, 19(1), 307.

Atakro, C. (2017). Experiences of student nurses and midwives at selected hospitals in the Volta region of Ghana. British Journal of Education, Society and Behavioral Science, 21(4), 1-9.

Bäck, L., Sharma, B., Karlström, A., Tunon, K., \& Hildingsson, I. (2017). Professional confidence among Swedish final year midwifery students-a cross-sectional study. Sexual \& reproductive healthcare, 14, 69-78.

Baraz, R. Memarian, and Z. Vanaki, (2015). "Damaged professional identity as a barrier to Iranian nursing students' clinical learning: a qualitative study," Journal of Clinical Nursing and Midwifery, vol. 3, no. 3, pp. 1-15.

Bvumbwe, T., \& Mtshali, N. (2018). Nursing education challenges and solutions in Sub Saharan Africa: An integrative review. BMC nursing, 17(1), 3.

Çalım, S., Ulaş, S., Demirci, H., \& Tayhan, E. (2020). Effect of simulation training on students' childbirth skills and satisfaction. Nurse Education in Practice, 102808.

Canobbio, M., Warnes, C., Aboulhosn, J., Connolly, H., Khanna, A., Koos, B. \& Stout, K. (2017). Management of pregnancy in patients with complex congenital heart disease: a scientific statement for healthcare professionals from the American Heart Association. Circulation, 135(8), e50-e87. 
Coldridge, L., \& Davies, S. (2017). “Am I too emotional for this job?" An exploration of student midwives' experiences of coping with traumatic events in the labor ward. Midwifery, 45, 1-6.

Eswi A., And El Sayed Y. (2015): The experience of Egyptian male student nurses during attending maternity nursing clinical course, Nurse Education in Practice 11 (2015) $93 \mathrm{e} 9$.

Gaberson, K., Oermann, M., and Shellenbarger T. (2014): Clinical Teaching Strategies in Nursing, Springer, New York, NY, USA, 2014.

Hallin, K., \& Danielson, E. (2014): Being a personal preceptor for nursing students: Registered Nurses' experiences before and after introduction of a preceptor model. Journal of advanced nursing, 65(1), 161-174.

Jan, L., \& Popescu, L. (2014). Israel's Nursing Students' Stress Sources and Coping Strategies During Their First Clinical Experience in Hospital Wards-A Qualitative Research. Social Work Review/ Revista de Asistenta Sociala, 13(4

Joolaee, S. R. Jafarian, M. A. Farahani, and S. varaei, "Iranian nursing students' preparedness for clinical training: a qualitative study," Nurse Education Today, vol. 20, no. 3, pp. 310-318, 2014.

Kalkhoran, M. Karimollahi, M. and R. Abdi, R. "Iranian staff nurses' attitudes toward nursing students," Nurse Education Today, vol. 31, no. 5, pp. 477-481, 2013.

Kwashie, A. A. (2019). Experiences of Ghanaian Student Nurses in the Clinical Learning Environment: Implications for Nursing Education and Practice (Doctoral dissertation, University of Ghana.

Mainey, L., O’Mullan, C., Reid-Searl, K., Taylor, A., \& Baird, K. (2020). The role of nurses and midwives in the provision of abortion care: A scoping review. Journal of Clinical Nursing, 29(9-10), 1513- 1526.

Manninen, E. "Changes in nursing students' perceptions of nursing as they progress through their education," Journal of Advanced Nursing, vol. 27, no. 2, pp. 390-398, 2012.

Marzouk, T. (2015). Effectiveness of simulated delivery room classes on practical achievement and satisfaction of maternity nursing students. Journal of Nursing Education and Practice, 5(8), 51-59.

Millanzi, W. C., \& Kibusi, S. M. (2020). Exploring the Effect of Problem Based Facilitatory Teaching Approach on Motivation to Learn in Nursing Education: A QuasiExperimental Study of Nurse Students in Tanzania

Nabolsi, M. Zumot, A. Wardam, L. and Abu-Moghli, F. "The experience of Jordanian nursing students in their clinical practice," Procedia-Social and Behavioral Sciences, vol. 46, pp. 5849-5857, 2012. 
Nasser, H., Mostafa, M., \& Fathy, N. (2018). Perception of Junior Nurse Students and Nurse Interns Regarding Public Image of Nursing. Egyptian Journal of Health Care, 9(2), 34-47.

National League for Nursing. Position statement: Transforming nursing education. 2013; New York.

Nishimi, K., \& Street, N. W. (2020). Nursing education partnerships between western high-income universities and non-governmental agencies and low-income local agencies: A scoping review of the literature. Journal of Professional Nursing, 36(3), 147157.

Yousefy, A., Yazdannik, R. and Mohammadi, S. "Exploring the environment of clinical baccalaureate nursing students' education in Iran; A qualitative descriptive study," Nurse Education Today, vol. 35, no. 12, pp. 1295-1300, 2015.

Weber, P. (2016). Closing the know-do gap in public health professional training: the case-method teaching approach. Ann. Behav. Med, 50(1), S1-S335Atakro CA, Gross J (2016). Preceptor ship versus clinical teaching partnership: Literature review and recommendations for implementation in Ghana. Adv in Nurs; 1-5.

Yacob, O. (2019). Intersectionalities and access in fieldwork in post conflict Liberia: Motherland, motherhood, and minefields. African Affairs, 118(470), 168-181.

Zboril, L. (2016). Why nurses are calling in sick: the impact of health-care restructuring. Canadian Journal of Nursing Research Archive, 33(4).

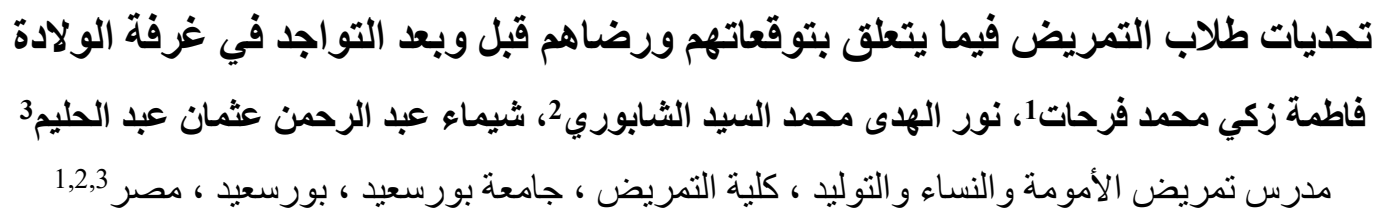

\section{الخلاصة}

الخلفية: تعتبر مهنة التوليد وتمريض النساء والتوليد ديناميكية وصعبة ، وحيث ان قبول او عدم قبول الطلاب من المتو اجدين اثثاء التدريب في أجنحة او اقسام العمل بالمستشفيات يؤثر على تعلم الطلاب وتدريبهم العملي. لذلك فان . هدف البحث: هدفت الدر اسة إلى تقييم تحديات طلاب التمريض فيما يتعلق بتوقعاتهم ورضاهم قبل وبعد التو اجد في غرفة الو لادة للتنريب العملي وتعلم الو لادة. طرق وادوات البحث: تم استخدام تصميم در اسة وصفية استكثافية على 91 طالب وطالبة تمريض بالمعهد الفني الصحي شعبة التمريض كانو ا يحضرون وحدة الولادة بقسم النساء و التوليد أثناء دراسة كورس تمريض الأمومة وحديثي الو لادة في العام الدراسي 2018-2019 في مستشفى دمياط العام بمدينة دمياط ، مصر. الأدوات: تم جمع البيانات باستخدام استبيان ذاتي مكون من ثلاثة أجز اء تم تطويره وتعديله من قبل الباحثين ، ويتضمن أسئلة حول توقعات طلاب التمريض قبل وبعد دخول او حضور غرفة الولادة ، معرفة الطلاب بالعمل بغرفة الولادة ونسبة رضاهم عن اداء التدريب العملي، وكذلك تم استخدام مقياس معدل لقياس الخبرة العلمية لطلاب التمريض فيما 
يتعلق بتوقعاتهم ورضاهم. النتائج: فيما يتعلق بتوقعات الطلاب ، توقع أكثر من ثلثي الطلاب أن يتم الترحيب بهم من

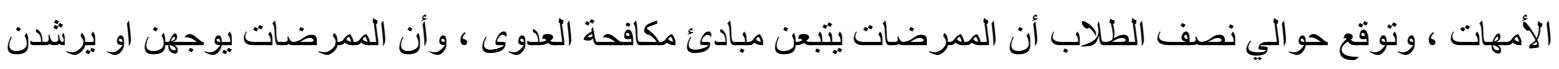
النساء فيما يتعلق بتعليمات الولادة ، وكان أقل بقليل من ثلثي الطلاب راضين عن حضورهم التدريب العملي بغرفة الو لادة وشعور هم بالانتماء و الهوية. الاستتتاجات: يواجه طلاب التمريض العديد من التحديات في التدريب العملي او لون

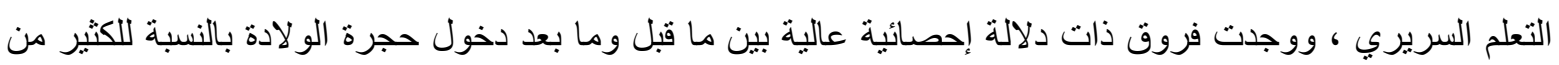
توقعاتهم ، وقد تحققت بعض من توقعات الطلاب.و كان الطلاب راضين عن إنجاز اتهم السريرية بعد حضور هم غرفة الو لادة. التوصيات: تنفيذ برامج لتوجيه الطلاب قبل الحضور إلى غرفة الو لادة ، وتشمل كيفية إعداد الطلاب وكيفية

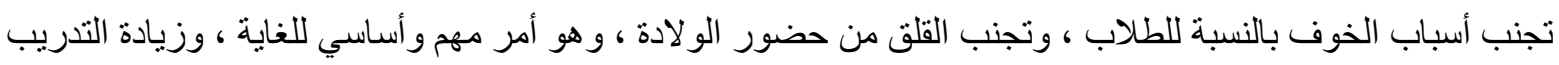

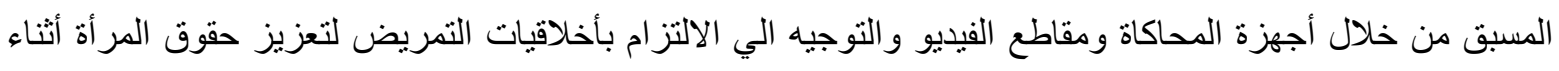
الو لادة.

الكلمات المرشدة: التحديات ، غرفة الولادة ، التوقعات ، طلاب التدريض ، الرضا. 